\title{
Diet quality assessment indexes
}

\section{Índices de avaliação da qualidade da dieta}

Kênia Mara Baiocchi de CARVALHO'

Eliane Said DUTRA'

Nathalia PIZATO'

Nádia Dias GRUEZO'

Marina Kiyomi ITO'

\section{A B S T R A C T}

Various indices and scores based on admittedly healthy dietary patterns or food guides for the general population, or aiming at the prevention of diet-related diseases have been developed to assess diet quality. The four indices preferred by most studies are: the Diet Quality Index; the Healthy Eating Index; the Mediterranean Diet Score; and the Overall Nutritional Quality Index. Other instruments based on these indices have been developed and the words 'adapted', 'revised', or 'new version I, II or III' added to their names. Even validated indices usually find only modest associations between diet and risk of disease or death, raising questions about their limitations and the complexity associated with measuring the causal relationship between diet and health parameters. The objective of this review is to describe the main instruments used for assessing diet quality, and the applications and limitations related to their use and interpretation.

Indexing terms: Diet. Diet mediterranean. Indexes.

\section{R E S U M O}

Para avaliação da qualidade da dieta, diferentes índices ou escores foram desenvolvidos, considerando padrões dietéticos reconhecidamente saudáveis ou baseando-se em guias alimentares para populações em geral ou para a prevenção de doenças. Dos vários índices, quatro deles servem de base para a maior parte dos estudos: Índice de Qualidade da Dieta, Índice de Alimentação Saudável, Escore da Dieta Mediterrânea e Índice Geral de Qualidade Nutricional. A partir desses modelos, alguns outros foram criados, com acréscimo do termo adaptado/ revisado, ou em novas versões (I, II ou III) como referência do respectivo original. Esses índices, mesmo validados, apresentam associações geralmente modestas com o risco de mortalidade ou doenças, o que aponta suas limitações, bem como a complexidade de se medir a relação causal entre dieta e parâmetros de saúde. Esta revisão tem como objetivo descrever os principais instrumentos de avaliação da qualidade da dieta, assim como suas aplicações e limitações, relativas ao uso e interpretações.

Termos de Indexação: Dieta. Dieta mediterrânea. Índices.

${ }^{1}$ Universidade de Brasília, Faculdade de Ciências da Saúde, Programa de Pós-Graduação em Nutrição Humana. Campus Universitário Darcy Ribeiro, Asa Norte, 70910-900, Brasília, DF, Brasil. Correspondência para/Correspondence to: KMB CARVALHO. E-mail: <kenia@unb.br>. 


\section{NTRODUCTION}

Despite the amount of knowledge on the benefits of a nutritionally balanced to prevent chronic Non-Communicable Diseases (NCD), the prevalence of these diseases has been increasing. NCD are associated with high intake of processed, energy-dense, low-nutrient foods ${ }^{1-3}$.

The relationship between diet and health is very complex and cannot be attributed to a single dietary component. Epidemiologic studies that investigate NCD-related dietary factors found that the Western diet is a risk factor ${ }^{4-7}$, and a diet high in fruits and non-starchy vegetables is protective ${ }^{6,8}$. More specifically, sometimes dietary fat is the key risk factor either because of quality or quantity ${ }^{3,9}$. Other times sugar or the high intake of ultra-processed foods is considered the greatest threat to human health ${ }^{10}$, increasing the risk of obesity and associated diseases ${ }^{10-12}$.

Food patterns reflect individual preferences influenced by genetic and environmental factors. Today the environment is highly obesogenic, driven mainly by the vested interest of the food and advertising industries. Studies of food patterns allow assessing their global health effects on a population ${ }^{13,14}$, hence the great interest in this subject.

Different diet quality assessment indices or scores have been developed based on admittedly healthy dietary patterns or food guides for the general population, or aiming to prevent diet-related diseases ${ }^{15}$. Parameters such as macronutrient distribution and a balance between the food groups are usually present. These instruments allow the monitoring of dietary changes in population groups. They are also used in cross-sectional or temporal individual assessment to assess their results.

Currently, nutritional epidemiology proposes two methods for analyzing dietary patterns more comprehensively: a priori analysis, which includes the use of diet quality scores based on food guides or admittedly healthy diets ${ }^{16}$, and a posteriori analysis, which uses multivariate statistical methods to investigate the dietary pattern of the study population ${ }^{17-19}$.

Even validated diet quality scores usually find only modest associations between diet and risk of death or diseases ${ }^{15}$, suggesting the complexity of their causal relationship and instrument limitations. The accuracy of these instruments depends on the tester's ability to understand the characteristics of the various individual or group indices and their capabilities and limitations, which may be facilitated by reviewing pertinent studies ${ }^{13}$.

Given the importance of the relationship between diet and NCD, the objective of this review is to describe the main instruments used for assessing diet quality a priori (Mediterranean Diet Score) and a posteriori (Diet Quality Index, Healthy Eating Index, Overall Nutritional Quality Index) and the applications and limitations associated with their use and interpretation.

\section{METHODS}

Studies on diet quality scores and their validations and uses published by June 2014 were searched in the database Web of Science using the keywords "diet quality index", "Mediterranean diet", "diet score", and "health eating index". Studies published in English, Portuguese, and Spanish were selected. Original and review articles were included. Of the fifty studies found, ten were excluded because they did not include the study subject as the study objective $(n=3)$, or regarded diseases such as liver diseases, diabetes, cancer, and neurological diseases $(n=7)$. Based on the pertinence of the subject for this review, the references cited in the articles were also included, as well as classic studies about different dietary assessment indices.

\section{RESULT AND DISCUSSION}

The four dietary assessment indices used by most studies are: the Diet Quality Index (DQI) ${ }^{20}$, 
Healthy Eating Index $(\mathrm{HEI})^{21}$, Mediterranean Diet Score (MDS) 22,23 , and the Overall Nutritional Quality Index (ONQI) ${ }^{24}$. Some other instruments have been developed using these indices as reference and the words 'adapted', 'revised', or 'new version' added to their names in reference to the original (Table 1).

\section{Diet Quality Index}

The original Diet Quality Index ${ }^{20}$ was developed to assess the intake of eight food groups and the recommendations of the Committee on Diet and Health of the National Research Council Food and Nutrition Board ${ }^{39}$ and of the United States government. Drewnowski et al. ${ }^{25}$ presented a simplified DQI version (DQI-a I), adapted for a dietary survey in France. In this adaptation, a maximum score of five points reflected the following attributes: (1) less than $30 \%$ energy from fats; (2) less than 10\% energy from saturated fats; (3) cholesterol intake up to
300 mg per day; (4) more than 50\% energy from carbohydrates; and (5) less than 10\% energy from sucrose. These parameters were assessed in absolute terms (yes/no). In addition to these five DQI elements, the authors scored variety (dietary variety) and diversity (number of food groups present in the diet). Thus, this index excluded the parameters protein, sodium, calcium, and fruit and non-starchy vegetable servings, present in the original version.

In a second adaptation (DQI-a II), this same group of researchers modified one of the five DQI-a I score points, replacing the parameter 'less than $10 \%$ energy from sucrose' by the parameter 'sodium intake below 2,500 mg'. Again dietary variety score was assessed separately. The authors used this instrument to compare the dietary patterns of American youth and older individuals by recording food intake during fourteen consecutive days. A significant association was not found between diet variety and DQI-a $\|^{26}$, suggesting that the component 'variety' proposed by this instrument still presented limitations.

Table 1. Diet quality assessment indices and studies that introduced or used them.

\begin{tabular}{|c|c|}
\hline Diet quality assessment indices (originally in English) & Reference (year) \\
\hline Diet Quality Index (DQI) & Patterson et al. $(1994)^{20}$ \\
\hline Adapted Diet Quality Index (DQI-a I) & Drewnowski et al. $(1996)^{25}$ \\
\hline Adapted Diet Quality Index (DQI-a II) & Drewnowski et al. $(1997)^{26}$ \\
\hline Revised Diet Quality Index (DQI-R) & Haines et al. $(1999)^{27}$ \\
\hline International Diet Quality Index (DQI-I ) & Kim et al. $(2003)^{28}$ \\
\hline Healthy Eating Index (DQI) & Kennedy et al. $(1995)^{21}$ \\
\hline HEl-2005 & Guenther et al. (2008) $)^{29}$ \\
\hline HEI-2010 & Guenther et al. $(2013)^{30}$ \\
\hline Brazilian Diet Quality Index (BDQI) & Fisberg et al. (2004) $)^{31}$ \\
\hline HEI adaptation to the Brazilian Food Guide (HEl-ad) & Mota et al. (2008) 32 \\
\hline Brazilian Diet Quality Index revised (BDQI-R) & Previdelli et al. (2011) ${ }^{33}$ \\
\hline Mediterranean Diet Score (MDS), original and modified & Trichopoulou et al. (1995) ${ }^{22}$; Trichopoulou et al. $(2003)^{23}$; Hu et al. $(2002)^{34}$. \\
\hline Mediterranean Dietary Pattern adherence index (MDP) & Sanchez-Villega et al. $(2002)^{35}$ \\
\hline Cardioprotective Mediterranean diet index (Cardio) & Martinez-Gonzalez et al. (2004) $)^{36}$ \\
\hline Mediterranean-Dietary Quality Index (Med -DQI) & Gerber $(2006)^{37}$ \\
\hline Mediterranean Style Dietary Pattern Score (MSDPS) & Rumawas et al. (2009)38 \\
\hline Overall Nutritional Quality Index (ONQI) & Katz et al. $(2009)^{24}$ \\
\hline
\end{tabular}


Later, changes in the American Food Guide Pyramid and Dietary Reference Intakes (DRI) were included in the Revised DQI (DQI-R), which introduced the measurement of food proportionality, moderation, and variety as dietary quality parameters ${ }^{27}$. Proportionality regards the recommendation of consuming a higher number of servings of certain food groups and a fewer number of other food groups. The parameter moderation involves limiting the intake of food components that contribute to health risk, such as fat, salt, and sugar. Finally, variety includes interand intragroup variety, consequently, consumption of more food components. This instrument, with a maximum score of 100 points, is based on the food pyramid and the DRIs for calcium and iron. Table 2 shows the DQI-R components.

In order to allow the comparison of food patterns between countries based not only on the association between diet and NCD but also on the risk of malnutrition still present in the epidemiological transition, Kim et al. ${ }^{28}$ proposed the international DQI (DQI-I). These authors compared the food practices between China and the United States and assessed the dietary patterns of the two countries using concepts of variety, adequacy, moderation, and balance. The

Table 2. Revised Diet Quality Index (IQD-R) components ${ }^{27}$.

\begin{tabular}{|c|c|c|}
\hline Component & Score & Assessment levels \\
\hline Total fat $\leq 30 \%$ of the energy consumed & 0-10 points & $\begin{array}{c}\leq 30 \%=10 \\
>30 \%, \leq 40 \%=5 \\
>40 \%=0\end{array}$ \\
\hline Saturated fat $\leq 10 \%$ of the energy consumed & 0-10 points & $\begin{array}{c}\leq 10 \%=10 \\
>10 \%, \leq 13 \%=5 \\
>13 \%=0\end{array}$ \\
\hline Dietary cholesterol $<300$ mg/day & $0-10$ points & $\begin{array}{c}\leq 300 \mathrm{mg}=10 \\
>300 \mathrm{mg}, \leq 400 \mathrm{mg}=5 \\
>400 \mathrm{mg}=0\end{array}$ \\
\hline Two to four servings of fruits per day, \% of recommended servings & 0-10 points & $\begin{array}{c}\geq 100 \%=10 \\
99 \%-50 \%=5 \\
<50 \%=0\end{array}$ \\
\hline $\begin{array}{l}\text { Three to five servings of non-starchy vegetables per day, \% of } \\
\text { recommended servings }\end{array}$ & $0-10$ points & $\begin{array}{c}\geq 100 \%=10 \\
99 \%-50 \%=5 \\
<50 \%=0\end{array}$ \\
\hline Six to eleven servings of grains per day, \% of recommended servings & $0-10$ points & $\begin{array}{c}\geq 100 \%=10 \\
99 \%-50 \%=5 \\
<50 \%=0\end{array}$ \\
\hline Calcium intake as $\%$ Al by age, $\%$ of recommended intake & 0-10 points & $\begin{array}{c}\geq 100 \%=10 \\
99 \%-50 \%=5 \\
<50 \%=0\end{array}$ \\
\hline Iron intake as \% RDA by age & $0-10$ points & $\begin{array}{c}\geq 100 \%=10 \\
99 \%-50 \%=5 \\
<50 \%=10\end{array}$ \\
\hline Diet diversity score & $0-10$ points & $\begin{array}{c}\geq 6 \\
\geq 3,<6 \\
<3\end{array}$ \\
\hline Food moderation score & $0-10$ points & $\begin{array}{c}\geq 7 \\
\geq 4,<7 \\
<4\end{array}$ \\
\hline
\end{tabular}

Note: Al: Adequate Intake; RDA: Recommended Dietary Allowances. 
dietary components were extensively assessed, including food pyramid inter- and intragroup variety; intake of certain nutrients (iron, calcium, vitamin C, fat, sodium), cholesterol, and empty calories; and macronutrient and fatty acid ratios (poly-, mono-, and saturated fatty acids). Although the instrument allows the comparison of many dietary elements, the numerous variables and extensive information required to assess adequacy introduce a level of complexity that hinders its use.

Other Diet Quality Index proposals have been developed for different populations and life stages ${ }^{40-42}$, each with specific characteristics. The existence of multiple revised and adapted DQI instruments not only hinders the understanding of their assessment focus but also limits the possibility of comparing the dietary surveys of different population groups.

\section{Health Eating Index}

The Healthy Eating Index (HEI) was developed by Kennedy et al..$^{21}$ to investigate American eating habits and their compliance with the dietary guidelines provided by the Recommended Dietary Allowances (RDA) of the U.S. Departments of Agriculture (USDA) and of Health and Human Services in 1980. The HEl was developed by the USDA (1989-1990), and it is updated at every five years.

The original Healthy Eating Index analyzes five food and nutrient groups, namely grains, vegetables, fruits, milk and dairy products, and meats, which receive a score of 0 to 10 according to the number of servings consumed from each group. Diet variety and some nutrients, such as total fat, saturated fat, cholesterol, and sodium, are also scored 0 to 10 points. Diet quality increases with score (Table 3).

The subsequent $\mathrm{HEI}$ updates, namely HEl-200529 and HEl-201030, changed the food groups and nutrients but maintained the direct relationship between diet quality and score. The current subdivision is represented by food groups separated by compliance criteria and intake moderation. Compliance parameters included total fruit (including juices); whole fruits (except juices); total vegetables (including all types of beans and peas not included in the total protein sources); green vegetables and beans (including all types of beans and peas not included in the total protein sources); whole grains; milk and dairy products; total protein sources; seafood and plant protein (including nuts, seeds, and soybean products); and fatty acids (the ratio between polyand monounsaturated fatty acids to saturated fatty acids). Moderation parameters include refined grains, sodium, and empty calories (solid fats, alcohol, and added sugar).

The scores are still based on the amount of energy coming from each group expressed as energy density (serving/1,000 kcal). For the compliance parameter, the scores are highest when intake equals or exceeds the RDA. In the moderation parameter, the maximum score indicates an intake equal to or below the RDA.

Generally, the HEl assesses diet quality and appropriateness of consumed food groups and nutrients. The results may indicate a need of nutritional interventions for specific groups or populations.

\section{Mediterranean Diet Score}

The term 'Mediterranean Diet' refers to the dietary pattern found in areas that produce olive oil in this geographic region. The first scientific evidence that Mediterranean populations had lower incidence of cardiovascular diseases appeared in the 1960s, which was attributed to a non-westernized $\operatorname{diet}^{43}$. In 1986 while studying the dietary habits of Mediterranean communities, Keys et al. ${ }^{44}$ named that dietary pattern the 'Mediterranean Diet', to which they bluntly attributed relatively low rates of cardiovascular diseases and neoplasms. Currently, the term is used in the scientific literature not only to describe a specific diet, but also a set of dietary habits traditionally followed by populations of countries 
Table 3. Components and score standards versions HEI-1990, HEI-2005, and HEl-2010.

\begin{tabular}{|c|c|c|c|}
\hline \multirow{2}{*}{$\begin{array}{l}\text { Components of the Healthy } \\
\text { Eating Indexes }\end{array}$} & \multicolumn{3}{|c|}{ Score } \\
\hline & Points & Maximum & Minimum \\
\hline HEI-1990 (Kennedy et al., 1995)21 & Score & Maximum score (10 points) & Minimum score (0 points) \\
\hline \multicolumn{4}{|l|}{ Food groups } \\
\hline Grains & 0 to 10 & 6-11 servings & 0 serving (no intake) \\
\hline Vegetables & 0 to 10 & 3-5 servings & 0 serving \\
\hline Fruits & 0 to 10 & $2-4$ servings & 0 serving \\
\hline Milk & 0 to 10 & 2 a 3 servings & 0 serving \\
\hline Meat & 0 to 10 & 2 a 3 servings & 0 serving \\
\hline \multicolumn{4}{|l|}{ Recommendations } \\
\hline Total fat & 0 to 10 & $\leq 30 \%$ of the tei ${ }^{1}$ & $\geq 45 \%$ of the tei \\
\hline Saturated fat & 0 to 10 & less than $10 \%$ of the tei & $\geq 15 \%$ of the tei \\
\hline Cholesterol & 0 to 10 & less than $300 \mathrm{mg}$ & $\geq 0 f 450 \mathrm{mg}$ \\
\hline Sodium & 0 to 10 & less than $2.4 \mathrm{~g}$ & $\geq 0 f 4.8 \mathrm{~g}$ \\
\hline Diet variety & 0 to 10 & $\begin{array}{l}\text { intake of } 16 \text { types of foods over three } \\
\text { days }\end{array}$ & $\begin{array}{l}\text { intake of } 6 \text { or fewer types of foods over } \\
\text { three days }\end{array}$ \\
\hline HEl-2005 (Guenter et al., 2008) & Score & Maximum score (5 a 10 points) & Minimum score (0 points) \\
\hline \multicolumn{4}{|l|}{ Group adequacy } \\
\hline Total fruits & 5 & $\geq 0.8$ cup per $1,000 \mathrm{kcal}$ & no intake \\
\hline Whole fruits & 5 & $\geq 0.4$ cup per $1,000 \mathrm{kcal}$ & no intake \\
\hline Total vegetables & 5 & $\geq 1.1$ cups per $1,000 \mathrm{kcal}$ & no intake \\
\hline $\begin{array}{l}\text { Dark green and orangish } \\
\text { vegetables and legumes }\end{array}$ & 5 & $\geq 0.4$ cup per $1,000 \mathrm{kcal}$ & no intake \\
\hline Total grains & 5 & $\geq 3.0$ ounces $^{2}$ per $1,000 \mathrm{kcal}$ & no intake \\
\hline Whole grains & 5 & $\geq 1.5$ ounces per $1,000 \mathrm{kcal}$ & no intake \\
\hline Milk & 10 & $\geq 1.3$ cups per $1,000 \mathrm{kcal}$ & no intake \\
\hline Meat and beans & 10 & $\geq 2.5$ ounces per $1,000 \mathrm{kcal}$ & no intake \\
\hline Oils & 10 & $\geq 12 \mathrm{~g}$ per $1,000 \mathrm{kcal}$ & no intake \\
\hline \multicolumn{4}{|l|}{ Group moderation } \\
\hline Saturated fat & 10 & $\leq 07 \%$ of the tei & $\geq 15 \%$ of the tei \\
\hline Sodium & 10 & $\leq 0.7$ g per $1,000 \mathrm{kcal}$ & $\geq 2,0 \mathrm{~g}$ per $1,000 \mathrm{kcal}$ \\
\hline Sofaas Calories & 20 & $\leq 20 \%$ of the tei & $\geq 50 \%$ of the tei \\
\hline HEI-2010 (Guenter et al., 2013)30 & Score & Maximum score (5 a 10 points) & Minimum score (0 points) \\
\hline \multicolumn{4}{|l|}{ Group adequacy } \\
\hline Total fruits & 5 & $\geq 0.8$ cup per $1,000 \mathrm{kcal}$ & no intake \\
\hline Whole fruits & 5 & $\geq 0.4$ cup per $1,000 \mathrm{kcal}$ & no intake \\
\hline Total vegetables & 5 & $\geq 1.1$ cups per $1,000 \mathrm{kcal}$ & no intake \\
\hline Green vegetables and beans & 5 & $\geq 0.2$ cup per $1,000 \mathrm{kcal}$ & no intake \\
\hline Whole grains & 10 & $\geq 1.5$ ounces per $1,000 \mathrm{kcal}$ & \\
\hline Dairy products & 10 & $\geq 1.3$ cups per $1,000 \mathrm{kcal}$ & no intake \\
\hline Total protein sources & 5 & $\geq 2.5$ ounces per $1,000 \mathrm{kcal}$ & no intake \\
\hline Seafood and plant protein & 5 & $\geq 0.8$ ounces per $1,000 \mathrm{kcal}$ & no intake \\
\hline Fatty acids & 10 & $($ Pufas + Mufas)/saturated $>2.5$ & no intake \\
\hline Group moderation & 10 & $\leq 1.8$ ounces per $1,000 \mathrm{kcal}$ & \\
\hline Refined grains & 10 & $\leq 1.1 \mathrm{~g}$ per $1,000 \mathrm{kcal}$ & $\geq 4.3$ ounces per $1,000 \mathrm{kcal}$ \\
\hline Sodium & 20 & $\leq 19 \%$ of the tei & $\geq 2,0 \mathrm{~g}$ per $1,000 \mathrm{kcal}$ \\
\hline Empty calories & & & $\geq 50 \%$ of the tei \\
\hline
\end{tabular}

Note: ${ }^{1}$ Total energy intake; ${ }^{2}$ Ounce: 1 ounce equals $28,35 \mathrm{~g}$.

SoFAAS: Solid Fats, Alcoholic beverages, and Added Sugar; PUFA: Polyunsaturated Fatty Acids; MUFA: Monounsaturated Fatty Acids. 
bordering the Mediterranean Sea ${ }^{45}$. Later, other studies confirmed and provided new pieces of epidemiologic evidence that the traditional Mediterranean Diet, along with healthy life habits, may protect against NCD, such as coronary artery disease, stroke, diabetes type $2^{46}$, and obesity ${ }^{47}$, and reduce inflammatory and coagulation processes ${ }^{48}$. Indeed, high adherence to the Mediterranean diet is associated with a low risk of inappropriate nutrient intake ${ }^{49}$.

In summary, the Mediterranean Diet is characterized by high intake of olive oil (main source of lipids), non-starchy vegetables, legumes, whole grains, and fruits, including nuts; moderate intake of poultry and fish (depending on proximity to the coast); low intake of whole milk and dairy products and red meats; and low to moderate intake of wine as the main source of alcohol during the meals ${ }^{45}$. Over time, other foods were incorporated because more information regarding the traditional Mediterranean Diet of reference became available, which included less typical foods such as eggs, animal fats, margarine, beverages with added sugar, cakes, pies, cookies, and sugar ${ }^{50,51}$.

Generally, indices that estimate adherence to the Mediterranean Diet were constructed using deduction, that is, by combining specific components ordered by cut-off points, later added to compose a final score. The number of components (foods, food groups, or a combination of nutrients, foods, and food groups); classification categories for each component; assessment scales; statistical parameters (mean, median, or daily intake cut-off amounts); and the positive or negative contribution of each component to the total score varied greatly between indices, resulting in an important variation in internal consistency ${ }^{52}$.

Originally, Trichopoulou et al. ${ }^{22}$ proposed an index that gave its components a positive or nil score and called it the Mediterranean Diet Score (MDS), developed to measure the degree of adherence to the traditional Mediterranean diet. This diet was characterized by eight components as follows: (1) higher consumption of monounsaturated than saturated fatty acids; high intake of (2) fruits and nuts; (3) non-starchy vegetables; (4) legumes; and (5) starches (including potatoes); moderate intake of (6) alcohol; low intake of (7) meat and meat products and (8) milk and dairy products. Later they added the group (9) seafood ${ }^{34}$. The MDS scored items 0 to 1 depending on the daily intake of each of its nine components. The cut-off points were given by the study sample's median intake of each component by gender ${ }^{23}$. Each 'protective' component, such as fruits and non-starchy vegetables, received a score of one if an individual's intake exceeded the median intake; or a score of zero if an individual's intake was equal to or below the median intake. Each 'nonprotective' component (like meats and dairy products) received a score of one if an individual's intake was below the median intake; and a score of zero if an individual's intake was equal to or above the median intake. For alcohol, one point was given to men who consumed $10 \mathrm{~g}$ to $50 \mathrm{~g}$ per day and to women who consumed $5 \mathrm{~g}$ to 25 $\mathrm{g}$ per day. The MDS varied from zero, meaning a minimum adherence to the traditional Mediterranean diet, to 9, meaning maximum adherence.

There are other indices that add or subtract standardized components to express adherence to the Mediterranean diet as a relative percentage. One such index is the Mediterranean Dietary Pattern Adherence Index (MDP) ${ }^{35}$. Initially, the intake of each component is adjusted for energy, and the result is standardized as a Z-score (mean and standard deviation). The total Z-score is given by adding all the Z-scores of the 'protective' components and subtracting the Z-scores of the 'nonprotective' components. Finally, the relative percentage of adherence to the Mediterranean diet is calculated by using the maximum and minimum Z-scores of the sample.

In the Cardioprotective Mediterranean Diet Index (CARDIO) $)^{36}$, six protective (olive oil, 
fibers, fruits, non-starchy vegetables, fish, and alcohol) and nonprotective food items (meat and meat products, and foods with high glycemic index) were defined. Intakes of protective and nonprotective foods were divided into quintiles. Each participant received a positive score of 1 (smallest) to 5 (highest), corresponding to his protective food intake quintile, and a negative score of 1 to 5 corresponding to his nonprotective food intake quintile. Later, a second post hoc index was constructed using only one cut-off point for these eight food components/groups, according to the dose-response relationship between the intake of each and the risk of myocardial infarction given by analyses based on the intake quintile of each food item.

When the original Diet Quality Index ${ }^{20}$ was administered to a sample of the Mediterranean population, it was inadequate to classify the population in that there was no gradient of consumption with increasing scores, resulting in the Mediterranean Diet Quality Index (Med$\mathrm{DQI})^{37}$. In this instrument, the olive oil score was inversely proportional to its intake. The item 'protein' was replaced by meat because fish was also scored proportionally and inversely to intake. Each group of nutrients or foods received a score from 0 to 2 based on the recommended intake, or if no recommendation existed, the score was based on the population's intake tertiles. The total score of each component was calculated and added to give a total Med-DQI score that decreases with diet healthiness.

The Mediterranean-Style Dietary Pattern Score (MSDPS) ${ }^{38}$ was developed for the American population and is based on the recommended amounts of the 13 food groups of the Mediterranean Diet Pyramid ${ }^{53}$. Each food group receives a score from 0 to 10 according to compliance with the recommended intakes. The score decreases as the degree of exceedance of the recommendations increases. The maximum score was standardized to 100 points and weighted proportionally to the energy intake from Mediterranean diet foods, that is, these foods received higher weights.
Panagiotakos et al. ${ }^{54,55}$ created a similar instrument called "MedDietScore", an index that estimates the level of adherence to the Mediterranean Diet, and a software based on this index that calculates adherence and its association with cardiovascular risk.

Although methodological issues regarding the Mediterranean Diet composition and its ability to identify health risks remain weaknesses, these indices have been used by many studies to investigate the association between adherence to the Mediterranean Diet and risk of NCD ${ }^{19}$.

\section{Overall Nutritional Quality Index}

Yale University researchers proposed a way for assessing the overall nutritional quality of foods called Overall Nutritional Quality Index $(\mathrm{ONQI})^{24}$. A multidisciplinary team of experts in nutrition and public health began this project in 2003 in an attempt to develop a food assessment method that takes into account the food's nutritionally beneficial and detrimental components. They created an extensive algorithm with more than 30 nutritional parameters and weight coefficients. The coefficients represented the possible epidemiological associations between a nutrient and its respective NCD-related outcomes. The result of the algorithm was a score attributed to each food. Hence, the scores ONQI attributed to foods enabled consumers to make healthier food choices.

Overall Nutritional Quality Index scores foods from 1 to 100 based on their nutritional characteristics. Higher scores mean lower risk of NCD ${ }^{24}$.

The algorithm, based on a literature review, selected nutrients based on scientific evidence of their health effects. Nutrients with beneficial health effects are placed in the numerator and those with detrimental health effects are placed in the denominator. Therefore, higher values reflected higher ONQI score. Table 4 shows the main nutrients included in the 
Table 4. Nutrients and macronutrient factors of the Overall Nutritional Quality Index (ONQI) algorithm²4.

\begin{tabular}{lll}
\hline Nutrients in the numerator (beneficial) & Nutrients in denominator (not beneficial) & Macronutrient factors \\
\hline Fiber & Saturated fat & Fat quality \\
Folate & Trans fat & Protein quality \\
Vitamin A, C, D, E, $\mathrm{B}_{6}$, and $\mathrm{B}_{12}$ & Sodium & Energy density \\
Potassium & Sugar (total/added) & Glycemic load \\
Calcium & Cholesterol & \\
Zinc & & \\
Omega-3 fatty acids & & \\
Bioflavonoids & \\
Carotenoids & \\
Magnesium & \\
Iron &
\end{tabular}

algorithm. Some nutritional factors, such as fat and protein quality, were placed in the numerator, while energy density and glycemic load were placed in the denominator.

In addition to the abovementioned nutritional aspects, another key element of this algorithm was the use of a dietary parameter. The dietary contribution of each food was also assessed. In other words, the researchers determined how the nutrient content of a food contributed to its daily requirement. Furthermore, this parameter also indicated how consuming a food could affect the recommended intake of its other nutrients. This parameter was named Trajectory Score (TS) ${ }^{24}$.

Overall Nutritional Quality Index content, construct, criterion, and face (tested the acceptance of the questionnaire by consumers at a supermarket) validation tests were performed. The results were highly significant, and regression analysis indicated excellent agreement between ONQI and HEl diet scores ${ }^{24}$. Later, the authors published new validation tests using data from the 2003-2006 National Health and Nutrition Examination Survey (NHANES) and provided a platform called Nutritional Guidance System NuVal (http://www.nuval.com), where foods have ONQI scores according to their nutritional quality ${ }^{56}$.

Chiuve et al. ${ }^{57}$ prospectively assessed whether ONQI was capable of predicting lower
NCD risk using data from more than 60 thousand individuals followed from 1986 to 2006 by the Nurses' Health Study. All foods consumed by the participants at baseline received ONQI scores, with subsequent calculation of their diet's mean ONQI score. The researchers found that consumption of foods with high ONQI scores was associated with a modest reduction in the risk of NCD and all-cause mortality.

However, the algorithm is not of public domain, it is only available online. The absence of validation studies comparing ONQI with a gold standard is a limitation for its use ${ }^{58}$. The ONQI is an alternative system developed for the American population and because it scores foods individually instead of scoring the diet, its use is unique.

\section{Use of the indices on the Brazilian population}

In Brazil, Fisberg et al. ${ }^{31}$ adapted and validated the original $\mathrm{HE}^{21}$ and named it Brazilian Diet Quality Index (BDQI). This DQI adapted for the Brazilian population Índice de Qualidade da Dieta Brasileira (IDQB) does not use the same variables as the original American $\mathrm{DQ}^{20}$. The similar names may cause confusion in data analyses and interpretation when studies that use these indices are compared.

The Brazilian Diet Quality Index includes dietary nutrients, foods, and constituents in a 
combined manner with regard to the dietary recommendations. Its score is also based on HEl-199521, that is, it scores the intake of food group servings and specific nutrients. In this study ${ }^{21}$, the authors found an association between diet quality and demographic and socioeconomic factors and lifestyle habits, and identified possibly vulnerable population groups.

The Brazilian Diet Quality Index was updated and revised for the publication of the 2006 Brazilian Food Guide ${ }^{59}$ since the latter is based on diet quality, given by correct food group intake. Previdelli et al. ${ }^{33}$ published the BDQI Revised (BDQI-R) similar to HEI-2005, which scores according to the amount of energy consumed from each food group.

In order to verify BDQI-R's reliability and validity, Andrade et al. ${ }^{60}$ used the 24-hour recall to analyze the dietary habits of a subsample of 2,375 people from the city of São Paulo. The $\mathrm{BDQ} \mathrm{I}-\mathrm{R}$ was analyzed for content, construct, and discriminant validity; and reliability. The authors suggest that the BDQI-R has good reliability to assess and monitor the diet quality of the Brazilian population.

Freitas et al. ${ }^{61}$ made a literature review on the diet quality of older Brazilians and found that $28 \%$ of the studies used the BDQI-R to analyze diet quality, suggesting that this instrument can be used not only for the general population but also for this group. Other studies used the $B D Q I-R$ in adolescents and also found that this tool can be used in this specific group with satisfactory results ${ }^{62-64}$.

Mota et al. ${ }^{32}$ made another adaptation of the HEl-1995 21 to the Brazilian population based on the Brazilian Food Guide ${ }^{59}$ and the Adapted Food Pyramid ${ }^{65}$. The resulting index was named Healthy Eating Index adapted (HEl-ad). The ideal number of servings was changed to match those proposed by the Adapted Food Pyramid, and the groups 'legumes', 'sweets and sugars', and 'fats and oils' were included, and the item 'sodium' was excluded. The HEl-ad scores a total of twelve components and classifies the diet as a) good quality (score $>100$ points); b) needs improvement (71 $\leq$ score $\leq 100$ points); and c) poor quality (score $<71$ points). Another study used the HEl-ad for assessing the diet quality of hypertensive individuals and found that high-quality diets were associated with smaller changes in systolic blood pressure ${ }^{66}$.

Thomazella etal. ${ }^{67}$ used the Cardioprotective Mediterranean Diet Index ${ }^{36}$ to compare the effects of the Mediterranean Diet and a low-fat diet on 42 men with a history of coronary events but found no significant differences between the two dietary patterns.

Monteiro et al. ${ }^{64}$ created a new food classification system that reflected the extent and purpose of commercial food processing (unprocessed or minimally processed foods; processed ingredients; and ultra-processed foods). The system aimed to investigate the impact of such foods on the global quality of the diet of Brazilian families. It is used in the current version (publicly available in May 2014) of the Brazilian Food Guide ${ }^{68}$, which recommends the consumption of unprocessed or homemade foods over ready-toeat foods and ultra-processed foods. Other Brazilian $^{64,69,70}$, Colombian ${ }^{71}$, and Canadian ${ }^{72}$ studies have also discussed the intake of ultraprocessed foods, used the new classification system to assess specific populations ${ }^{69,71}$, and associated the intake of ultra-processed foods with chronic diseases $^{73}$.

\section{FINAL CONSIDERATIONS}

The results show the importance of choosing appropriate indices to assess diet quality. Not understanding the types of indices and using them incorrectly in professional practice is common, whether due to poor translation, excessive number of adaptations, or similarity between assessment parameters.

Even validated diet assessment instruments generally find modest associations between diet 
and the risk of diseases and death, raising issues such as their limitations and the complexity involved in measuring the causal relationship between diet and health parameters.

Therefore, these instruments should be used with caution not only with respect to the method of administration but also to the possible inferences made from their results.

\section{CONTRIBUTORS}

KMB CARVALHO was responsible for defining the topics, methodology of bibliographic search and writing the first version of the manuscript. All the authors contributed for the final version, including content, bibliography and form.

\section{REFERENCES}

1. World Health Organization. Diet, nutrition and the prevention of chronic diseases. Geneva: WHO; 2003. Technical Report Series, $n^{\circ} 916$.

2. Drake I, Gullberg B, Sonestedt E, Wallstrom P, Persson M, Hlebowicz J, et al. Scoring models of a diet quality index and the predictive capability of mortality in a population-based cohort of Swedish men and women. Public Health Nutr. 2013; 16(3):468-78.

3. Willett WC, Stampfer ML. Current evidence on healthy eating. An Rev Public Health. 2013; 34(34):77-95

4. Hu FB, Willett WC. Optimal diets for prevention of coronary heart disease. JAMA. 2002; 288(20): 2569-78.

5. Baxter AJ, Coyne T, McClintock C. Dietary patterns and metabolic syndrome: A review of epidemiologic evidence. Asia Pacific J Clin Nutr. 2006; 15(2):134-42.

6. World Cancer Research Fund. Food, nutrition, and the prevention of cancer: A global perspective. Washington (DC): AICR; 2007.

7. Hlebowicz J, Drake I, Gullberg B, Sonestedt E, Wallstrom $\mathrm{P}$, Persson $\mathrm{M}$, et al. A high diet quality is associated with lower incidence of cardiovascular events in the Malmo Diet and Cancer Cohort. PLOS ONE. 2013; 8(8). doi: 10.137/jornal.pone.0071095

8. Boeing $H$, Bechthold A, Bub A, Ellinger S, Haller D, Kroke $A$, et al. Critical review: Vegetables and fruit in the prevention of chronic diseases. Eur J Nutr. 2012; 51(6):637-63.
9. Skerrett PJ, Willett WC. Essentials of healthy eating: A guide. J Midwifery Womens Health. 2010; 55(6):492-501.

10. Kaluza J, Hakansson N, Brzozowska A, Wolk A. Diet quality and mortality: A population-based prospective study of men. Eur J Clin Nutr. 2009; 63(4):451-7.

11. Monteiro CA, Levy RB, Claro RM, Ribeiro de Castro $I R$, Cannon G. Increasing consumption of ultraprocessed foods and likely impact on human health: Evidence from Brazil. Public Health Nutr. 2011; 14(1):5-13.

12. Zarrin R, Ibiebele TI, Marks GC. Development and validity assessment of a diet quality index for Australians. Asia Pac J Clin Nutr. 2013; 22(2):177-87.

13. Ocke MC. Evaluation of methodologies for assessing the overall diet: Dietary quality scores and dietary pattern analysis. Proc Nutr Soc. 2013; 72(2):191-9.

14. Kant AK. Dietary patterns and health outcomes. J Am Diet Assoc. 2004; 104(4):615-35.

15. Waijers PMCM, Feskens EJM, Ocke MC. A critical review of predefined diet quality scores. Br J Nutr. 2007; 97(2):219-31.

16. Hoffmann K, Zyriax BC, Boeing H, Windler E. A dietary pattern derived to explain biomarker variation is strongly associated with the risk of coronary artery disease. Am J Clinical Nutr. 2004; 80(3):633-40.

17. Kastorini C-M, Papadakis G, Milionis HJ, Kalantzi K, Puddu P-E, Nikolaou V, et al. Comparative analysis of a-priori and a-posteriori dietary patterns using state-of-the-art classification algorithms: A case/case-control study. Artif Intell Med. 2013; 59(3):175-83.

18. Bach A, Serra-Majem L, Carrasco JL, Roman B, Ngo J, Bertomeu I, et al. The use of indexes evaluating the adherence to the Mediterranean diet in epidemiological studies: A review. Public Health Nutr. 2006; 9(1A):132-46.

19. Kourlaba G, Panagiotakos DB. Dietary quality indices and human health: A review. Maturitas. 2009; 62(1):1-8.

20. Patterson RE, Haines PS, Popkin BM. Diet quality index: Capturing a multidimensional behavior. J Am Diet Assoc. 1994; 94(1):57-64.

21. Kennedy ET, Ohls J, Carlson S, Fleming K. The healthy eating index: Design and applications. J Am Diet Assoc. 1995; 95(10):1103-8.

22. Trichopoulou A, Kourisblazos A, Wahlqvist ML, Gnardellis C, Lagiou P, Polychronopoulos E, et al. Diet and overall survival in elderly people. $\mathrm{Br}$ Med J. 1995; 311(7018):1457-60. 
23. Trichopoulou A, Costacou T, Bamia C, Trichopoulos D. Adherence to a Mediterranean diet and survival in a Greek population. New Engl J Med. 2003; 348(26):2599-608.

24. Katz DL, Njike VY, Faridi Z, Rhee LQ, Reeves RS, Jenkins DJA, et al. The stratification of foods on the basis of overall nutritional quality: The overall nutritional quality index. Am J Health Promo. 2009; 24(2):133-43.

25. Drewnowski A, Henderson SA, Shore AB, Fischler C, Preziosi P, Hercberg S. Diet quality and dietary diversity in France: Implications for the French paradox. J Am Dietetic Assoc. 1996; 96(7):663-9.

26. Drewnowski A, Henderson SA, Driscoll A, Rolls BJ. The dietary variety score: Assessing diet quality in healthy young and older adults. J Am Diet Assoc. 1997; 97(3):266-71.

27. Haines PS, Siega-Riz AM, Popkin BM. The Diet Quality Index Revised: A measurement instrument for populations. J Am Diet Assoc. 1999; 99(6):697-704.

28. Kim S, Haines PS, Siega-Riz AM, Popkin BM. The Diet Quality Index - International (DQI-I) provides an effective tool for cross-national comparison of diet quality as illustrated by China and the United States. J Nutr. 2003; 133(11):3476-84

29. Guenther PM, Reedy J, Krebs-Smith SM, Reeve BB. Evaluation of the Healthy Eating Index - 2005. J Am Diet Assoc. 2008; 108(11):1896-901.

30. Guenther PM, Casavale KO, Reedy J, Kirkpatrick $\mathrm{SI}$, Hiza HAB, Kuczynski KJ, et al. Update of the Healthy Eating Index: HEl-2010. J Acad Nutr Diet. 2013; 113:569-80.

31. Fisberg RM, Slater B, Barros RR, Lima FDd, Cesar CLG, Carandina L, et al. Índice de Qualidade da Dieta: avaliação da adaptação e aplicabilidade. Rev Nutr. 2004; 17(3):301-18. doi: 10.1590/S1415-52 732004000300003

32. Mota JF, Madalena Rinaldi AE, Pereira AF, Maesta $\mathrm{N}$, Scarpin MM, Burini RC. Adaptação do índice de alimentação saudável ao guia alimentar da população brasileira. Rev Nutr. 2008; 21(5):545-52. doi: 10.1590/S1415-52732008000500007

33. Previdelli AN, Andrade SC, Pires MM, Gouvea Ferreira SR, Fisberg RM, Marchioni DM. A revised version of the Healthy Eating Index for the Brazilian population. Rev Saúde Pública. 2011; 45(4):794-8.

34. Hu FB, Bronner L, Willett WC, Stampfer MJ, Rexrode $\mathrm{KM}$, Albert CM, et al. Fish and omega-3 fatty acid intake and risk of coronary heart disease in women. JAMA. 2002; 287(14):1815-21.

35. Sanchez-Villegas A, Martinez JA, Irala J, MartinezGonzalez MA, Grp SUNR. Determinants of the adherence to an "a priori" defined Mediterranean dietary pattern. Eur J Nutr. 2002; 41(6):249-57.
36. Martinez-Gonzalez MA, Fernandez-Jarne E, Serrano-Martinez M, Wright M, Gomez-Gracia E. Development of a short dietary intake questionnaire for the quantitative estimation of adherence to a cardioprotective Mediterranean diet. Eur J Clin Nutr. 2004; 58(11):1550-2.

37. Gerber M. Qualitative methods to evaluate Mediterranean diet in adults. Public Health Nutr. 2006; 9(1A):147-51.

38. Rumawas ME, Dwyer JT, McKeown NM, Meigs JB, Rogers $G$, Jacques PF. The Development of the Mediterranean-style dietary pattern score and its application to the american diet in the Framingham Offspring cohort. J Nutr. 2009; 139(6):1150-6.

39. National Research Council, Food and Nutrition Board. Recommended Dietary Allowances. $10^{\text {th }} \mathrm{ed}$. Washington (DC): National Academy Press; 1989.

40. Godoy FdC, Andrade SC, Morimoto JM, Carandina L, Goldbaum M, Barros MBA, et al. Índice de qualidade da dieta de adolescentes residentes no distrito do Butantã, município de São Paulo, Brasil. Rev Nutr. 2006; 19(6):663-71. doi: 10.1590/S1415-52 732006000600003

41. Kim EHJ, Willett WC, Fung T, Rosner B, Holmes MD. Diet quality indices and postmenopausal breast cancer survival. Nutr Cancer. 2011; 63(3):381-8.

42. Lassale C, Fezeu L, Andreeva VA, Hercberg S, Kengne AP, Czernichow $S$, et al. Association between dietary scores and 13-year weight change and obesity risk in a French prospective cohort. Int J Obes. 2012; 36(11):1455-62.

43. Trichopoulou, A. Mediterranean diet: The past and the present. Nutr Metabol Cardiovas. 2001; 11(4 Suppl):1-4.

44. Keys A, Menotti A, Karvonen MJ, Aravanis C, Blackburn H, Buzina R et al. The diet and 15-year death rate in the seven countries study. Am J Epidemiol. 1986; 124:903-15.

45. Sofi F. The Mediterranean diet revisited: Evidence of its effectiveness grows. Curr Opinion Cardiol. 2009; 24(5):442-6.

46. Willett WC. The Mediterranean diet: Science and practice. Public Health Nutr. 2006; 9(1A):105-10.

47. Panagiotakos DB, Chrysohoou C, Pitsavos C, Stefanadis $C$. Association between the prevalence of obesity and adherence to the Mediterranean diet: The ATTICA study. Nutrition. 2006; 22(5):449-56.

48. Chrysohoou C, Panagiotakos DB, Pitsavos C, Das UN, Stefanadis C. Adherence to the Mediterranean diet attenuates inflammation and coagulation process in healthy adults: The ATTICA study. J Am Coll Cardiol. 2004; 44(1):152-8. 
49. Castro-Quezada I, Roman-Vinas B, Serra-Majem L. The Mediterranean diet and nutritional adequacy: A review. Nutrients. 2014; 6(1):231-48.

50. Fidanza F. Who remembers the true Italian Mediterranean diet? Diabetes Nutr Metabol. 2001; 14(3):119-20.

51. Fidanza F, Alberti A, Lanti M, Menotti A. Mediterranean Adequacy Index: Correlation with 25-year mortality from coronary heart disease in the Seven Countries Study. Nutr Metabol Cardiovas. 2004; 14(5):254-8.

52. Mila-Villarroel R, Bach-Faig A, Puig J, Puchal A, Farran A, Serra-Majem L, et al. Comparison and evaluation of the reliability of indexes of adherence to the Mediterranean diet. Public Health Nutr. 2011; 14(12A):2338-45.

53. Willett WC, Sacks F, Trichopoulou A, Drescher G, Ferroluzzi A, Helsing $E$, et al. Mediterranean diet pyramid: A cultural model for healthy eating. Am J Clin Nutr. 1995; 61(6):S1402-S6.

54. Panagiotakos DB, Milias GA, Pitsavos C, Stefanadis C. MedDietScore: A computer program that evaluates the adherence to the Mediterranean dietary pattern and its relation to cardiovascular disease risk. Comput Meth Prog Biomed. 2006; 83(1):73-7.

55. Panagiotakos DB, Pitsavos C, Stefanadis C. Dietary patterns: A Mediterranean diet score and its relation to clinical and biological markers of cardiovascular disease risk. Nutr Metabol Cardiovas. 2006; 16(8):559-68.

56. Katz DL, Njike VY, Rhee LQ, Reingold A, Ayoob KT. Performance characteristics of NuVal and the Overall Nutritional Quality Index (ONQI). Am J Clin Nutr. 2010; 91(4):1102S-8S.

57. Chiuve SE, Sampson L, Willett WC. The association between a nutritional quality index and risk of chronic disease. Am J Prev Med. 2011; 40(5):505-13.

58. Reedy J, Kirkpatrick SI. The use of proprietary nutrient profiling tools in nutrition science and policy a commentary. Am J Prev Med. 2011; 40(5):581-2.

59. Brasil. Ministério da Saúde. Guia alimentar para a população brasileira: promovendo a alimentação saudável. Brasília: Ministério da Saúde; 2006. Série A. Normas e Manuais Técnicos, $n^{\circ} 210$.

60. Andrade SCd, Previdelli AN, Marchioni DML, Fisberg RM. Avaliação da confiabilidade e validade do Indice de Qualidade da Dieta Revisado. Rev Saúde Pública. 2013; 47(4):675-83.

61. Freitas TI, Previato M, Aquino RC, Buriti MA. Avaliação da qualidade da dieta de idosos no Brasil: produção científica sobre o tema. Rev Kairós Gerontol. 2013; 16(4):195-213.

62. Wendpap LL, Ferreira MG, Melo Rodrigues PR, Pereira RA, Loureiro AdS, Veras Goncalves-Silva RM.
Adolescents' diet quality and associated factors. Cad Saúde Pública. 2014; 30(1):97-106.

63. Andrade SC, Azevedo Barros MB, Carandina L, Goldbaum M, Galvão Cesar CL. Dietary Quality Index and associated factors among adolescents of the state of São Paulo, Brazil. J Pediatr. 2010; 156(3):456-60.

64. Monteiro CA, Levy RB, Claro RM, Ribeiro de Castro IR, Cannon G. A new classification of foods based on the extent and purpose of their processing. Cad Saúde Pública. 2010; 26(11):2039-49.

65. Philippi ST, Latterza AR, Cruz ATR, Ribeiro LC. Pirâmide alimentar adaptada: guia para escolha dos alimentos. Rev Nutr. 1999; 12(1):65-80. doi: 10.1590/S1415-52731999000100006

66. Oliveira EP, Camargo KF, Fullin Castanho GK, Nicola M, Portero-McLellan KC, Burini RC. Dietary variety is a protective factor for elevated systolic blood pressure. Arq Bras Cardiol. 2012; 98(4):338-43.

67. Thomazella MCD, Goes MFS, Andrade CR, Debbas $V$, Barbeiro DF, Correia RL, et al. Effects of high adherence to mediterranean or low-fat diets in medicated secondary prevention patients. Am J Cardiol. 2011; 108(11):1523-9.

68. Brasil. Ministério da Saúde. Guia alimentar para a população brasileira: promovendo a alimentação saudável. Brasília: Ministério da Saúde; 2014.

69. Tavares LF, Fonseca SC, Garcia Rosa ML, Yokoo EM. Relationship between ultra-processed foods and metabolic syndrome in adolescents from a Brazilian Family Doctor Program. Public Health Nutr. 2012; 15(1):82-7.

70. Marrocos Leite FH, Oliveira MA, Cremm EC, Costa de Abreu DS, Maron LR, Martins PA. Availability of processed foods in the perimeter of public schools in urban areas. J Pediatr. 2012; 88(4):328-34.

71. Mallarino C, Gómez LF, González-Zapata L, Cadena Y, Parra DC. Advertising of ultra-processed foods and beverages: Children as a vulnerable population. Rev Saúde Pública. 2013; 47(5):1006-10.

72. Moubarac JC, Martins APB, Claro RM, Levy RB, Cannon G, Monteiro CA. Consumption of ultraprocessed foods and likely impact on human health: Evidence from Canada. Public Health Nutr. 2013; 16:2240-8.

73. Moodie R, Stuckler D, Monteiro C, Sheron N, Neal $B$, Thamarangsi $T$, et al. Profits and pandemics: Prevention of harmful effects of tobacco, alcohol, and ultra-processed food and drink industries. Lancet. 2013; 381(9867):670-9. 
